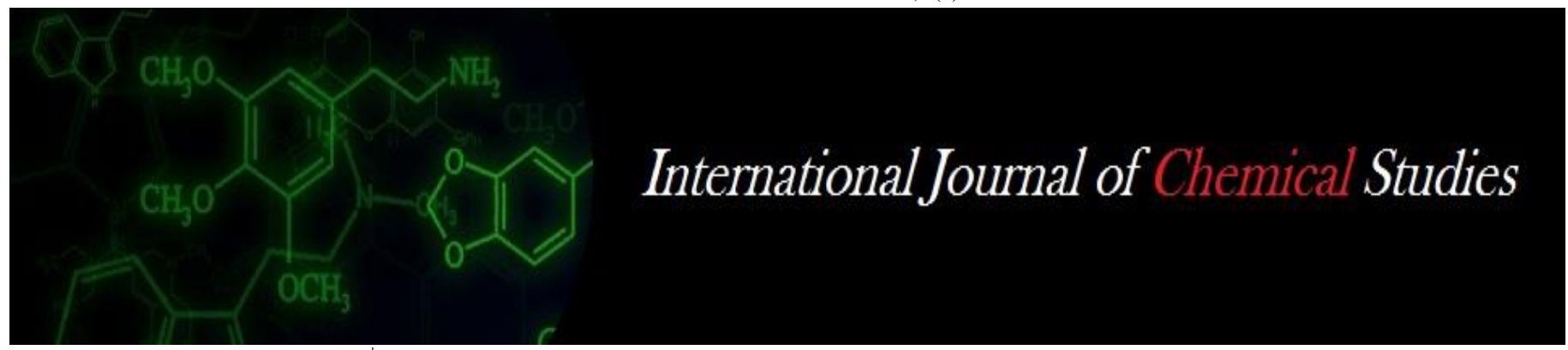

P-ISSN: 2349-8528

E-ISSN: 2321-4902

www.chemijournal.com

IJCS 2020; 8(4): 1841-1844

(C) 2020 IJCS

Received: 13-05-2020

Accepted: 15-06-2020

Jyoti

Ph.D. Scholar, Department of

Foods and Nutrition,

CCS Haryana Agricultural

University, Hisar, Haryana,

India

Sudesh Jood

Professor, Department of Foods and Nutrition,

CCS Haryana Agricultural

University, Hisar, Haryana,

India

Corresponding Author:

Jyoti

Ph.D. Scholar, Department of

Foods and Nutrition,

CCS Haryana Agricultural

University, Hisar, Haryana,

India

\section{Physicochemical and nutritional composition of composite flour enriched with spinach leaves powder for development of value-added baked products}

\section{Jyoti and Sudesh Jood}

DOI: https://doi.org/10.22271/chemi.2020.v8.i4s.9895

\begin{abstract}
The present study was conducted to see the effect of supplementation of spinach leaves in commonly consumed baked and traditional products. Five types of composite flours were formulated by using wheat flour, bengal gram flour and spinach leaves powder at (4, 6, 8, 10 and 12\% levels). Control-I (100\% wheat flour), Control-II (100\% bengal gram flour), Type-I composite flour (48:48:4), Type-II composite flour (47:47:6), Type-III composite flour (46:46:8), Type-IV composite flour (45:45:10), and Type-V composite flour (44:44:12), respectively. All the formulated composite flour samples were analyzed for their physico-chemical properties. It was observed that water absorption capacity, oil absorption capacity, swelling power, bulk density and least gelation capacity of composite flours increased significantly with increase in the level of incorporation of spinach powder. While solubility and flour dispersability were found to be decreased with increase in the level of spinach powder. Type-I composite flour showed highest values containing 4 per cent level of spinach powder while Type-V composite flour showed lower values containing 12 per cent level of incorporation. Moisture, crude protein, crude fat, crude fibre and ash content of all five types of composite flour samples were found significantly higher than the control sample (wheat flour) while in comparison to bengal gram flour (control), crude protein content in all five types of composite flour samples decreased due to replacement of bengal gram flour with wheat flour. Total iron, calcium, zinc, phosphorus, $\beta$-carotene, dietary fibre and anti-oxidant activity of all five types of composite flour found significantly higher than control sample.
\end{abstract}

Keywords: Composite flour, physico-chemical properties, baked products, nutritional composition

\section{Introduction}

The average diet in most of the Asian countries including India is predominantly cereal based. These diets have poor bioavailability of micronutrients leading to wide prevalence of irondeficiency, anaemia and vitamin ' $A$ '. Certain green leafy vegetables are a rich source of $\beta$ carotene, a precursor of vitamin ' $A$ ' and grown abundantly in India. The most commonly used leafy vegetables are spinach, fenugreek, drumstick leaves, shepu, coriander, mint, chakota and curry leaves etc. Since these have short life, suitable processing and preservation can prevent wastage and increase availability in the diet during off season. In developing countries multiple micronutrient deficiency are more common than single deficiency and the cause for their high prevalence is due to poor consumption and poor bioavailability of micronutrients (Gupta and Prakash 2011) ${ }^{[6]}$.

The nutritive value of staple food can be enhanced through a mutual complementation of their restrictive micronutrients with value added ingredients. Green leafy vegetables and legumes are among the value added ingredients and multi-cultural components used ubiquitously in Indian cuisine. Green leafy vegetables and legumes are rich source of protein, micronutrients and dietary fibre (Galla et al. 2017; Longvah et al. 2017; Singh et al. 2018) ${ }^{[4,12,18]}$.

Today due to urbanisation and lack of time to prepare food, there is a demand to have nutritious premixes which are ready to reconstitute and ready to prepare. There are various types of premixes like idli, dosa, gulab jamoon premixes etc. are available in market, chapati premix fortified with nutrient rich green leafy vegetables are not available. Therefore, attempts were made to develop chapati premixes by fortifying wheat flour with dehydrated spinach powder and to evaluate their effect on physico-chemical, rheological, nutritional and sensory characteristics. 


\section{Material and Methods}

\subsection{Procurement of materials}

Grain samples of a wheat variety (WH-1105) and a bengal gram variety (HC-1) were procured from the Department of Genetics and Plant Breeding, CCS Haryana Agricultural University, Hisar. The grain samples were cleaned, bengal gram seeds were dehulled and ground into flour. The ground samples were stored in plastic container till further use.

Spinach leaves (Spinacia oleracea L.) were procured in a single lot from local market of Hisar. Healthy mature and disease-free leaves were selected and washed under running tap water followed by distilled water. Excess water were wiped off with muslin cloth. Then the leaves were dried in the shade for 6 to $8 \mathrm{~h}$ to remove excess moisture followed by oven drying at $40-45^{\circ} \mathrm{C}$ till complete drying. The dried leaves were ground in an electric grinder to obtain a fine powder. The ground powder were stored in low density polyethylene (LDPE) bags for further use.

\subsection{Preparation of spinach leaves powder}

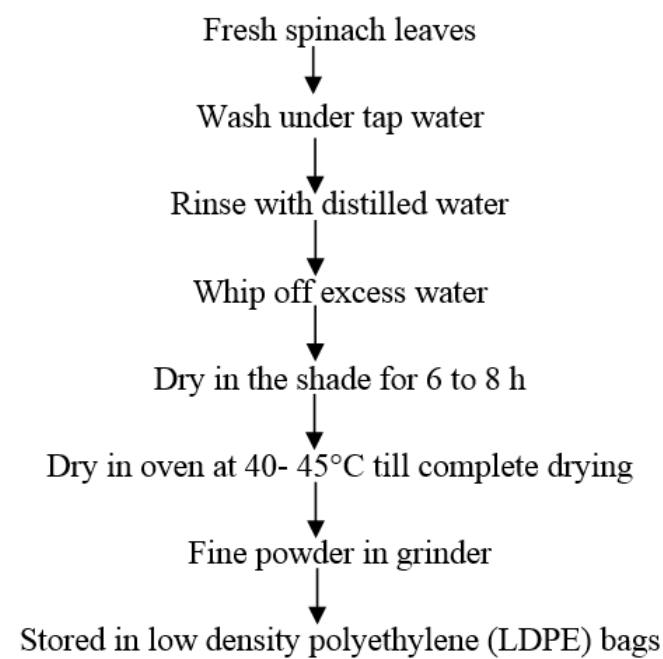

\subsection{Formulation of composite flour}

Different proportions of wheat flour, bengal gram flour and spinach leaves powder were used for formulation of composite flour. Five types of composite flour were prepared by using wheat flour, bengal gram flour and spinach leaves powder i.e in the ratio of 48:48:4 (Type-I), 47:47:6 (Type-II), 46:46:8 (Type-III), 45:45:10 (Type-IV) and 44:44:12 (TypeV).

\subsection{Nutritional evaluation}

The five types of composite flour samples were evaluated for physico chemical property by using different methods, proximate composition (AOAC, 2000) [2], For mineral estimation, the samples were wet acid digested, using a nitric acid and perchloric acid mixture (HNO3:HClO4, 5:1 w/v). The total amounts of $\mathrm{Ca}, \mathrm{Mg}, \mathrm{P}, \mathrm{Fe}$ and $\mathrm{Zn}$ in the digested samples were determined by Atomic Absorption Spectrophotometry (Lindsey and Norwell, 1969) [11]. Antioxidant activity was estimated by the method of Prieto et al., $1999^{[15]}$ and $\beta$-carotene was estimated by the method of $\operatorname{AOAC}(2000)^{[2]}$.

\section{Results and discussion}

\subsection{Physico-chemical properties of composite flour}

The data on physico-chemical properties of wheat flour, bengal gram flour and formulated composite flours by incorporating spinach powder, bengal gram flour in wheat flour at different levels viz., Type-I (WF:BGF:SP::48:48:4), Type-II (WF:BGF:SP::47:47:6), Type-III
(WF:BGF:SP::46:46:8), Type-IV (WF:BGF:SP::45:45:10) and Type-V (WF:BGF:SP::44:44:12) are presented in Table 1.

Water absorption capacity and oil absorption capacity of wheat flour were $(0.98 \mathrm{ml} / \mathrm{g})$ and $(1.23 \mathrm{~g} / \mathrm{g})$ while bengal gram flour had significantly lower water absorption capacity $(0.67 \mathrm{ml} / \mathrm{g})$ and oil absorption capacity $(0.78 \mathrm{~g} / \mathrm{g})$. In all types of composite flour, water absorption capacity and oil absorption capacity increased significantly from 1.50 to 3.20 $\mathrm{ml} / \mathrm{g}$ and 1.40 to $2.90 \mathrm{~g} / \mathrm{g}$, respectively as compared to control samples. Galla et al. (2017) ${ }^{[4]}$ reported that the increase in water absorption may be attributed to the fact that hydroxyl groups present in the fibre structure allow more water interaction through hydrogen bonding. Gomez et al. (2003) ${ }^{[5]}$ and Dachana et al. (2010) ${ }^{[3]}$ also reported addition of fibre increase the water absorption in composite flour made cookies and bread flour due to hydroxyl groups present in fibre. Similar results of water and oil absorption capacity were also reported by other workers in composite flours Ritika et al. (2016) ${ }^{[16]}$. High water and oil absorption capacity of composite flour can positively influenced the flavour, moisture and fat content of food (Prajapati et al. 2015) ${ }^{[14]}$. Swelling power of wheat flour and bengal gram flour was 7.85 and $5.28 \mathrm{~g} / \mathrm{g}$ while bulk density was $0.64 \mathrm{~g} / \mathrm{ml}$ for wheat flour and $0.68 \mathrm{~g} / \mathrm{ml}$ for bengal gram flour as these values were found to significantly and gradually increased in all five types of composite flour samples containing spinach leaves powder at $4,6,8,10$ and 12 per cent. Other workers also reported higher swelling power and bulk density in flour supplemented with green leafy vegetables (Ajibola et al. 2015; Galla et al. 2017) ${ }^{[1,4]}$.

Solubility and flour dispersability of wheat flour (control) were $0.72 \mathrm{~g} / \mathrm{g}$ and $19.76 \mathrm{~g} / 100 \mathrm{ml}$ which was found to be significantly decreased in all the five types of composite flour might be due to addition of spinach leaves powder. Flour dispersability is an index that measure how well flour or flour blends can be rehydrated with water Kulkarni et al. (1991) ${ }^{[9]}$. On other hand, least gelation capacity of control flours were found to be increased on supplementation of spinach leaves powder in wheat-bengal gram flour blends. Least gelation capacity of all five types of composite flour were in the range of 9.50 to $12.40 \mathrm{~g} / 100 \mathrm{ml}$. Similar results were also reported by Prajapati et al. (2015) ${ }^{[14]}$ and Ritika et al. (2016) ${ }^{[16]}$ in composite flour (14.00 to $18.70 \mathrm{~g} / 100 \mathrm{ml}$ ) as these results are in close agreement with the present results.

\subsection{Nutritional composition of composite flour}

Proximate composition: The table 2 is furnished with the results of proximate composition of composite flour.

Moisture content of control flour increased significantly with increase in incorporation level of spinach powder in wheatbengal gram flour blends. Other workers also reported higher moisture content in composite flour containing green leafy vegetables powder (Lakshmi \& Vimla 2000; Singh \& Grover 2014; Singh et al. 2018) ${ }^{[10,17,18]}$. In the present study crude protein, crude fat, crude fibre and ash content of five types of composite flour samples were in the range of 15.09 to 17.50 , 3.41 to $3.98,1.87$ to 2.79 and 2.11 to 3.52 per cent, respectively. As these contents were found to be significantly increased as compared to wheat flour (control) which might be due to addition of bengal gram flour and spinach powder in wheat flour (Table 2). Singh \& Grover (2014) ${ }^{[17]}$ also reported higher crude protein, fat, fibre and ash content in composite flour containing wheat-bengal gram flour and bengal gram leaves powder. As these results are similar as reported in present study. Other workers also reported higher crude protein, fat, fibre in composite flour containing green 
leafy vegetables (Pant et al. 2012; Ajibola et al. 2015; Singh et al. 2018) ${ }^{[13,1,18]}$.

Total minerals: Total minerals content of composite flour given in table 3 .

Total minerals ( $\mathrm{Fe}, \mathrm{Ca}, \mathrm{Zn}$ and $\mathrm{P}$ ), anti-oxidant activity and $\beta$ carotene content for all five types of composite flour were found to be significantly higher than control flour which might be due to addition of spinach powder up to 12 per cent levels. Type-I composite flour (containing 4 per cent level of spinach powder) exhibited lower content while Type-V composite flour (containing 12 per cent level of spinach powder) had higher content of $\mathrm{Ca}, \mathrm{P}, \mathrm{Fe}, \mathrm{Zn}$ (Table 3). Other workers also reported higher content of $\mathrm{Ca}, \mathrm{P}, \mathrm{Fe}, \mathrm{Zn}, \beta$ - carotene and anti-oxidant activity composite flour containing green leafy vegetables powders. (Umma Khair et al. 2012; Pant et al. 2012; Kavitha \& Ramadas 2013; Galla et al. 2017) $[20,13,7,4]$ reported that fresh spinach leaves are rich source of calcium $(1336 \mathrm{mg} / 100 \mathrm{~g})$, iron $(30 \mathrm{mg} / 100 \mathrm{~g})$ and phosphorus (336 mg/100g). Anti-oxidant activity $(1.4 \mathrm{mg} / \mathrm{ml})$ was also found higher in spinach leaves powder (Suresh \& Kalaivani 2016) ${ }^{[19]}$. Khan et al. $(2015)^{[8]}$ reported $1019.00 \mathrm{mg}$ calcium, $68.92 \mathrm{mg}$ iron, $5.06 \mathrm{mg}$ zinc, $32.59 \mathrm{mg}$ phosphorus and 2605 $\mu \mathrm{g} \beta$-carotene content in per $100 \mathrm{~g}$ of spinach leaves powder which contributed higher level of minerals and $\beta$-carotene in the composite flour. These results are in close agreement with results reported in present study in formulated composite flour samples (Table 4).

Table 1: Physico-chemical properties of different flours

\begin{tabular}{|c|c|c|c|c|c|c|c|c|}
\hline \multirow{2}{*}{ Physico-chemical properties } & \multirow{2}{*}{ WF $(100 \%)$} & \multirow{2}{*}{ BGF (100\%) } & \multicolumn{4}{|c|}{ Composite flours } & \multirow[b]{2}{*}{ Type-V } & \multirow{2}{*}{$\begin{array}{c}\text { C.D } \\
(\mathbf{P}=\mathbf{0 . 0 5})\end{array}$} \\
\hline & & & Type-I & Type-II & Type-III & Type-IV & & \\
\hline Water absorption capacity $(\mathrm{ml} / \mathrm{g})$ & $0.98 \pm 0.01^{*}$ & $0.67 \pm 0.01$ & $1.50 \pm 0.01$ & $1.96 \pm 0.01$ & $2.50 \pm 0.04$ & $2.90 \pm 0.04$ & $3.20 \pm 0.06$ & 0.11 \\
\hline Oil absorption capacity $(\mathrm{g} / \mathrm{g})$ & $1.23 \pm 0.02$ & $0.78 \pm 0.02$ & $1.40 \pm 0.03$ & $1.88 \pm 0.04$ & $2.24 \pm 0.05$ & $2.56 \pm 0.01$ & $2.90 \pm 0.07$ & 0.13 \\
\hline Swelling power $(\mathrm{g} / \mathrm{g})$ & $7.85 \pm 0.12$ & $5.28 \pm 0.04$ & $7.95 \pm 0.16$ & $8.05 \pm 0.03$ & $8.43 \pm 0.17$ & $8.89 \pm 0.09$ & $9.06 \pm 0.08$ & 0.39 \\
\hline Bulk density $(\mathrm{g} / \mathrm{ml})$ & $0.64 \pm 0.01$ & $0.68 \pm 0.01$ & $0.70 \pm 0.01$ & $0.75 \pm 0.02$ & $0.79 \pm 0.01$ & $0.84 \pm 0.02$ & $0.94 \pm 0.01$ & 0.03 \\
\hline Solubility $(\mathrm{g} / \mathrm{g})$ & $0.72 \pm 0.01$ & $0.52 \pm 0.01$ & $0.68 \pm 0.01$ & $0.61 \pm 0.01$ & $0.55 \pm 0.01$ & $0.42 \pm 0.01$ & $0.35 \pm 0.01$ & 0.02 \\
\hline Least gelation capacity $(\mathrm{g} / 100 \mathrm{ml})$ & 9.00 & 8.50 & 9.50 & 10.50 & 11.00 & 11.50 & 12.40 & 0.42 \\
\hline Flour dispersability $(\mathrm{g} / 100 \mathrm{ml})$ & $19.76 \pm 0.26$ & $15.54 \pm 0.15$ & $18.02 \pm 0.39$ & $16.56 \pm 0.06$ & $15.34 \pm 0.11$ & $14.79 \pm 0.34$ & $13.50 \pm 23$ & 0.89 \\
\hline
\end{tabular}

*Values are mean $\pm \mathrm{SE}$ of three independent determinations

Type-I: WF: BGF: SP (48:48:4) Type-II: WF: BGF: SP (47:47:6)

Type-III: WF: BGF: SP (46:46:8) Type-IV: WF: BGF: SP (45:45:10)

Type-V: WF: BGF: SP (44:44:12)

WF: Wheat flour BGF: Bengal gram flour SP: Spinach powder

Table 2: Proximate composition of different flour supplemented with spinach powder (\%, on dry matter basis)

\begin{tabular}{|c|c|c|c|c|c|c|c|c|}
\hline \multirow{2}{*}{$\begin{array}{c}\text { Proximate } \\
\text { Composition }\end{array}$} & \multirow{2}{*}{ WF 100\% } & \multirow{2}{*}{ BGF 100\% } & \multicolumn{5}{|c|}{ Composite flours } & CD \\
\cline { 4 - 8 }$(\mathbf{P}=\mathbf{0 . 0 5})$
\end{tabular}

** On wet matter basis *Values are mean \pm SE of three independent determinations

Type-I: WF: BGF: SP (48:48:4) Type-II: WF: BGF: SP (47:47:6)

Type-III: WF: BGF: SP (46:46:8) Type-IV: WF: BGF: SP (45:45:10)

Type-V: WF: BGF: SP (44:44:12)

WF: Wheat flour BGF: Bengal gram flour SP: Spinach powder

Table 3: Total mineral content of different flour supplemented with spinach powder ( $\mathrm{mg} / 100 \mathrm{~g}$, on dry matter basis)

\begin{tabular}{|c|c|c|c|c|c|c|c|c|}
\hline \multirow{2}{*}{ Total minerals } & \multirow{2}{*}{ WF 100\% } & \multirow{2}{*}{ BGF m100\% } & \multicolumn{5}{|c|}{ Composite flours } & \multirow{2}{*}{ CD $(P=0.05)$} \\
\cline { 4 - 8 } & & Type-I & Type-II & Type-III & Type-IV & Type-V & \\
\hline Iron & $3.55 \pm 0.02 *$ & $4.99 \pm 0.11$ & $5.14 \pm 0.07$ & $6.78 \pm 0.07$ & $7.89 \pm 0.02$ & $8.18 \pm 0.09$ & $8.89 \pm 0.08$ & 0.27 \\
\hline Calcium & $43.55 \pm 0.79$ & $58.00 \pm 0.23$ & $85.76 \pm 0.01$ & $123.14 \pm 3.01$ & $152.11 \pm 0.47$ & $193.26 \pm 0.40$ & $240.31 \pm 0.11$ & 4.32 \\
\hline Zinc & $1.98 \pm 0.02$ & $2.00 \pm 0.01$ & $2.34 \pm 0.05$ & $2.82 \pm 0.07$ & $3.01 \pm 0.02$ & $3.29 \pm 0.05$ & $3.63 \pm 0.07$ & 0.13 \\
\hline Phosphorus & $334.59 \pm 1.42$ & $339.25 \pm 1.15$ & $342.25 \pm 1.27$ & $354.10 \pm 1.84$ & $368.60 \pm 1.85$ & $374.52 \pm 2.11$ & $384.53 \pm 1.34$ & 5.35 \\
\hline
\end{tabular}

Table 4: Anti-oxidant activity and $\beta$-carotene content of different flour supplemented with spinach powder (on dry matter basis)

\begin{tabular}{|c|c|c|}
\hline Types of flours & Anti- oxidant activity (\%) & $\boldsymbol{\beta}$ - carotene( $\boldsymbol{\mu g} / \mathbf{1 0 0 g})$ \\
\hline WF $(100 \%)$ & $12.03 \pm 0.25^{*}$ & $3.87 \pm 0.23$ \\
\hline BGF $(100 \%)$ & $15.32 \pm 0.14$ & $159.89 \pm 0.58$ \\
\hline Type-I & $19.23 \pm 0.46$ & $172.29 \pm 0.94$ \\
\hline Type-II & $22.48 \pm 0.26$ & $240.69 \pm 0.28$ \\
\hline Type-III & $25.84 \pm 0.55$ & $265.42 \pm 0.69$ \\
\hline Type-IV & $29.76 \pm 0.24$ & $331.55 \pm 0.69$ \\
\hline Type-V & $33.61 \pm 0.71$ & 1.27 \\
\hline CD $(\mathrm{P}=0.05)$ & 1.52 & \\
\hline
\end{tabular}

*Values are mean $\pm \mathrm{SE}$ of three independent determinations

Type-I: WF: BGF: SP (48:48:4) Type-II: WF: BGF: SP (47:47:6)

Type-III: WF: BGF: SP (46:46:8) Type-IV: WF: BGF: SP (45:45:10)

Type-V: WF: BGF: SP (44:44:12)

WF: Wheat flour BGF: Bengal gram flour SP: Spinach powder 


\section{Conclusion}

It can be concluded that physico-chemical properties of composite flour such as water absorption capacity, oil absorption capacity, swelling power, bulk density and least gelation capacity of five types of composite flours increased significantly with increase in the level of incorporation of spinach powder. On the other hand, crude protein, crude fat, crude fiber, ash and mineral contents increased significantly in all five types of composite flour. Antioxidant activity and $\beta$-carotene content also increased significantly. Thus, dehydrated spinach powder have the potential to serve the valuable source of calcium, iron, fibre, vitamin ' $C$ ' and carotenoids in the diet of the population in India and other developing countries.

\section{References}

1. Ajibola CF, Oyerinde VO, Adeniyan OS. Physicochemical and antioxidant properties of wholewheat biscuits incorporated with Moringa oleifera leaves and cocoa powder. Journal of Scientific Research and Reports. 2015; 7(3):195-206.

2. AOAC. Official Methods of Analysis. $16^{\text {th }}$ Ed. Association of Official Analytical Chemists. Arlyngton, Virginia, USA, 2000.

3. Dachana KB, Rajiv J, Indrani D, Prakash J. Effect of dried moringa (Moringa oleifera L.) leaves on rheological, microstructural, nutritional, textural and organoleptic characteristics of cookies. Journal of Food Quality. 2010; 33:660-677.

4. Galla NR, Pamidighantam PR, Karakala B. Nutritional, textural and sensory quality of biscuits supplemented with spinach (Spinacia oleracea L.). Inter J of Gastro and Food Sci. 2017; 7:20-26.

5. Gomez M, Ronda F, Carlos A, Pedro B, Cballero A, Apesteguia A et al. Effect of dietary fibre on dough rheology and bread quality. Eur Food Res Technol. 2003; 216:51-56.

6. Gupta S. Prakash J. Nutritional and sensory quality of micronutrient-rich traditional products incorporated with green leafy vegetables. Int. Food Res. J. 2011; 18:667675.

7. Kavitha V, Ramadas VS. Nutritional composition of raw fresh and shade dried form of spinach leaf (Spinach oleracea). BioMedRx. 2013; 1(8):767-770.

8. Khan MA, Mahesh C, Semwal AD, Sharma GK. Effect of spinach powder on physico-chemical, rheological, nutritional and sensory characteristics of chapati premixes. J of Food Sci Technol. 2015; 52(4):2359-2365.

9. Kulkarni KD, Kulkarni DN, Ingle UM. Sorghum malted and soya bean weaning food formulation: preparation, functional properties and nutritive value. Food Nutrition Bulletin. 1991; 13:322-327.

10. Lakshmi B, Vimala V. Nutritive value of dehydrated green leafy vegetable powders. J of Food Sci and Technol. 2000; 37(5):465-471.

11. Lindsey WL, Norwell MA. A new DPTA-TEA soil test for zinc and iron. Agron. Abst. 1969; 61:84.

12. Longvah T, Ananthan R, Bhaskarachary K, Venkaiah K. Indian food composition tables. National institute of nutrition, 2017.

13. Pant R, Chawla R, Sadana B, Kushwaha S. Development and nutritional evaluation of cereal pulse based snacks using drumstick leaves. Agri Res J. 2012; 49(2):99-103.

14. Prajapati R, Chandra S, Samsher, Chauhan N, Singh GR, Kumar $\mathrm{S}$ et al. Effect of incorporation of flours on the functional properties of composite flours. South Asi J of Food Technol and Envi. 2015; 1(3):233-241.

15. Prieto P, Pineda M, Aguilar M. Spectrophotometric quantitation of antioxidant capacity through the formation of a phosphomolybdenum complex: Specific application to the determination of Vitamin E. Anal Biochemi. 1999; 269:337-341.

16. Ritika BY, Baljeet SY, Mahima S, Roshanlal Y. Suitability of wheat flour blends with malted and fermented cowpea flour noodle making. Int. Food Res. J. 2016; 23(5):2193-2202.

17. Singh A, Grover K. Post- harvest processing and standardization of value added cereal based traditional recipes for iron security. Asian Journal of Dairy and Food Res. 2014; 33(4):267-275.

18. Singh S, Yadav A, Sony A. Nutritional evaluation and sensory characteristics of products developed from waste leaves of cauliflower. Int. J Curr. Microbiol. App. Sci. 2018; 7:4782-4790.

19. Suresh L, Kalaivani AC. Nutritional activity, antioxidant and anti-arthritic activity of selected green leafy vegetables. Int. J. of Home Sci. 2016; 2(3):85-88.

20. Umma SK, Shinya O, Emiko Y, Yoshiya M. Phenolic acids, flavonoids and total antioxidant capacity of selected leafy vegetables. Journal of Functional Foods. 2012; 4(4):979-987. 